\title{
毁り点測定による非イオン界面活性剤の平均 オキシェチレン鎖長の決定
}

\author{
棌藤博・篠 时 耕 三

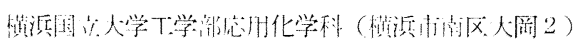

\author{
Determination of Average Oxyethylene Chain Length of Nonionic \\ Surfactants by Cloud Point Measurement \\ Hiroshi Saitō and Kōzō SHinOda \\ Department of Chemistry, Yokohama National University (Ooka-2, Minami-ku, Yokohama)
}

\begin{abstract}
The effect of the distribution of oxyethylene chain length of nonionic surfactants on the cloud point has been studied, using homogeneous $\left.\mathrm{C}_{12} \mathrm{H}_{25} \mathrm{O}\left(\mathrm{CH}_{2} \mathrm{CH}_{2} \mathrm{O}\right){ }_{n} \mathrm{H}(n=0) 8\right)$. The broader the distribution of oxyethylene chain length, the lower the cloud point becomes. A small deviation from Poisson distribution does not cause major difference in cloud point. The cloud point r's. oxyethylene chain length calibration curves for commercial $p, t-\mathrm{C}_{8} \mathrm{H}_{17} \mathrm{C}_{6} \mathrm{H}_{4} \mathrm{O}\left(\mathrm{CH}_{2} \mathrm{CH}_{2} \mathrm{O}\right)_{n}-\mathrm{H}$, $i$ $\mathrm{C}_{9} \mathrm{H}_{19} \mathrm{C}_{6} \mathrm{H}_{4} \mathrm{O}\left(\mathrm{CH}_{2} \mathrm{CH}_{2} \mathrm{O}\right)_{n}-\mathrm{H}$ and molecularly distilled $\mathrm{C}_{12} \mathrm{H}_{25}\left(\mathrm{CH}_{2} \mathrm{CH}_{2} \mathrm{O}\right)_{n}-\mathrm{H}$ were obtained. The distribution of oxyethylene chain length of these samples is close to the Poisson distribution. Byproduced polyethylene glycol does not affect appreciably to the cloud point. This cloud point measurement is relatively rapid and accurate for determining the average oxyethylene chain length of nonionic surfactant. While, determination of the oxyethylene chain length by other methods requires elimination of polyethylene glycol, water, etc, and also forces not only to consume the time but alters the distribution of oxyethylene chain length in the process of the elimination, these are the disadvantages of other methods.
\end{abstract}

\section{1 緒言}

非イオン界而活性济の諸作用はその平均親水基鎖長に よって非常に顥なるため，精度良く斗均鎖長を決めるこ とが必要である。吻均エレンオキシド鎖長 $(\bar{n})$ を求 める方法として，命成の祭のエチレンオキシドの吹き远 み量による直接咕算, $\mathrm{OH}$-值法, ヨウ化水素酸を用いる 方法のほか, NMR 法, 赤外抢よび紫外吸收を利用する 方法や曇り点を利用する方法などが知られているい,2》。

しかしエチレンオキシド付加の際，ポリエチレングリ コール (PEG 上略称する) が副成し曇り点法を除いた 方法では $\bar{n}$ 沈定に影響を寺える。そのため悬り点法を 除いたこれらの方法では PEG の除去が必要となり，そ の際界酒活性剂の $\bar{n}$ そのもと親水基鎖長分布も変化 してしまう場合がある。これに対し罝リ点と $\bar{n}$ との検 量線を利用した $\bar{n}$ 決定法は其存する PEGによのてほ とんど影響を受けず汶，率業品そのものを直接測定でき， 迅速で実験誤差のきわめて少ない方法と考えられる。に もかかわらず叟り点測定による も一般的でなか一たのは念成原料中の異性体やきょう雑
物の存在，親水基鎖長分布などに対する不安感があ一た ためとみられる。たとえばポリオキシエチレン・ノニル フェニルエーテルの場合に同じ $\bar{n}$ でもoーノニルフェノ

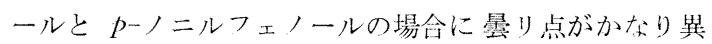
なることも報告されている ${ }^{4)}$ 。一方親水基鎖長分布湟 しても工業的に使用される Alkaline Catalysts ${ }^{5)}$ を用い て合成されたポリオキシエチレン・アルキルエーテルで は Weibull-Nycander 分布に近く ${ }^{6)}$, ポリオキシエチ レン・アルキルフェニルエーテルではほぼポアソン分布 になり (2 9) 界面活性羭の種類によって異なることや各分 布からのずれも多少あることが明らかである。本研究で はこれらの点を考慮して量り点測定による めの検量線を求めほかの方法との比較を試みた。

\section{2 実験}

\section{$2 \cdot 1$ 試料}

巣一鎖長ポリオキシエチレン $(\bar{n}=1 \sim 8)$ ドデシルエー テルは日光ケミカルズ株式会社製品で, 昇温ガスクロマ トグラフィーにより測定された純度が $98 \%$ 以上のもの を選んで使用した。各試料の $1 \mathrm{wt} \%$ 水溶液の量少点は 
闹様に単一鎖長のサンプルを用いて 測定された Tischbirek による曇リ点の結果 ${ }^{11)}$ とほとんど一致した。

分子蒸留品ポリオキシエチレン・ドデシルエーテルは 花王石喃株式会社の商業品を分子蒸留したもので，その 親水基鎖長分布は昇温ガスクロマトグラフィーによるボ アソン分布よりやや鋭いものを用いた。ポリオキシエチ レン・p-第三オクチルフェニルエーテルはやはり花王石 䖍よりの提供品で，原料のオクチルフ ェ ノールの組成は

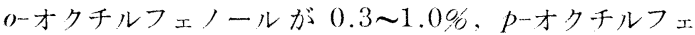
ノ一ルが98〜99\%,2,4-ジイソブチルフェノールがたか だか0.5\%であいた。またオクチル部はイソブチレンの ダイマーが 98〜99\%, イソブチレンと1-ブテンの codimerが1〜2\%よりないていた。ポリオキシエチレン・ ノニルフッニルエーテルは花王石粡株式会社製品で $p$ ノニルフォノールの制合が $95 \%$ 以上であのた。親水基 鎖长分布は舁温ガスクロマトグラフィーよりほぼポアソ ン分布であることを確かめた。

\section{$2 \cdot 2$ 遊離ポリエチレングリコールの除去}

試料の $8 \sim 20 \%$ 水溶液を曇り点以上の温度で充分に 振上うし静置の後, 分離した水相を除去する方法 ${ }^{12)} と$ のた。この操作を 6 回繰り返し得られた界再i活性剤連続 相を $70 \sim 100^{\circ} \mathrm{C}$ で減压乾燥した。あらかじめ平均分子 荲が 300 のポリエチレングリコールを試料に加え上記 の1回の操作で加えた量の約 $88 \%$ が除去されることを 確かめた。同時にこの操作で非イオン界面活性剂合成の 触媒を中和することによりできた無機塩も充分に除去さ れることを確かめてある。

\section{$2 \cdot 3$ 㦼り点測定}

界面活性剂の 1 5 wt \% 水溶液を試験管に入れ封じ てアンプルを作り，恒温ソウ中で充分に振とうしながら $10 \mathrm{~min}$ に約 $1^{\circ} \mathrm{C}$ 上昇させ白濁の現われる温度と, 逆に 高温から温度を下げ白濁の消える温度との中間の温度を 舅り点とした。その精度は土0.2 $2^{\circ}$ 以内であった。明 確に曇リ点の判断しにくい場合には長時間一定温度で恒 温ソウ中に保持し二相分離を示す限界の温度と, 均一相 を示す温度との中間の温度を曇り点とした。前者の方法 による雨り点は後者の值と一致した。

\section{$2 \cdot 4$ 平均ポリオキシエチレン鎖長の check}

通常の $\mathrm{OH}$-值測定法 ${ }^{13)}$ を用いて巣一鎖长のモノオキ シエチレン・ドデシルエーテル（純度 $99.7 \%)$ ，テトラ オキシェチレン・ドデシルエーテル（純度 $98 \% ） を$ をい て調心゙た結果前者で $n=0.99 \pm 0.02$, 後者で $3.97 \pm 0.04$ でありわれわれの実験 は充分の精度をもっていること (〜1\%内外) を確かめた。

\section{3 結果と考察}

\section{$3 \cdot 1$ 平均オキシエチレン鎖長決定法の検討}

はじめに平均オキシエチレン鎖長 $(\bar{n})$ 決定法につき
商業品中に共存するきょう雑物の影響を比較した。 $\bar{n}$ 決 定法のうち NMR 法 ${ }^{15}$ ) の精度は全水素に対し …2 $2 \%$ (1) （ポリオキシエチレン $(\bar{n}=10)$ ノニルフェニルエーテ

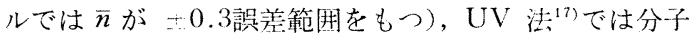
星が 1000 のボリオキシエチレン・アルキルエーテルで $\bar{n}$ が 0.3 の誤差範囲をもち，尖験の項で示したように $\mathrm{OH}$ 一值法の精度よりはるかに㧍ちる。そのため PEG 其 存の影響を（Ｈ一值法で比較した。一般にエチレンオキ シド付加の際水の其存により PEG が副成する ${ }^{5)}$ 。これ らの PEG は末端の $\mathrm{OH}$-基やエチレングリコール部分 のため $\bar{n}$ 決定に影響を年える。Table-1の 2) 上 3) で PEG（分子量 300) を約 $9 \%$ 加えたときの瞇り点と $\mathrm{OH}$-值法による $n$ の值の比較を示した。

Table-1 Effect of the added polyethylene glycol (MW $\fallingdotseq 300)$ on the oxyethylene chain length $(\bar{n})$ evaluated from $\mathrm{OH}$-value and cloud point of nonionic surfactant.

\begin{tabular}{|c|c|c|c|}
\hline \multicolumn{2}{|r|}{ Sample } & $\left(\begin{array}{c}\bar{n} \\
\text { evaluated } \\
\text { from }\end{array}\right)$ & $\begin{array}{l}\text { Cloud } \\
\text { point }\end{array}$ \\
\hline 1) & $\begin{array}{l}\text { iso- } \mathrm{C}_{9} \mathrm{H}_{19} \mathrm{C}_{6} \mathrm{H}_{4} \mathrm{O} \\
\left(\mathrm{CH}_{2} \mathrm{CH}_{2} \mathrm{O}\right)_{8.43} \mathrm{H} \\
\text { (commercial) }\end{array}$ & $8.43+0.03$ & 41.8 \\
\hline 2) & $\begin{array}{l}\text { Purified from sample } 1 \text { ) } \\
\text { (without polyethylene } \\
\text { glycol) }\end{array}$ & $8.56+0.03$ & 42.6 \\
\hline 3) & $\begin{array}{l}\text { Mixture of } 91.23 \% \text { of sam- } \\
\text { ple } 2) \text { and } 8.77 \% \text { of poly- } \\
\text { ethylene glycol }(\mathrm{MW} \fallingdotseq 300)\end{array}$ & $\frac{5.64+0.01}{(5.75)^{*}}$ & 41.5 \\
\hline
\end{tabular}

Cloud point of $1 \mathrm{wt} \%$ aqueous solution

* Calculated value

毁り点はわずか $1.1^{\circ} \mathrm{C}\left(\mathrm{PEG}\right.$ 含帤 $1 \%$ 当たり約 $\left.0.1^{\circ} \mathrm{C}\right)$ 変化するのに対し $\bar{n}$ は約 2.9 も変化している。実際の $\mathrm{PEG}$ の分子量はこれより多く，その平均鎖長は界面活

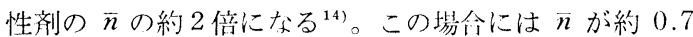
だけ変化する。表中 3）の実験值と咶算傎が良く一致し ており $\mathrm{OH}$-值法の精度が良いと考えられる。次に $\mathrm{PEG}$ 除去の影響を表中 1）と 2) で比較してみる。PEG 除 去前後でかりに界面活性浏の鎖铰分布が変わらないと仮

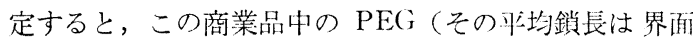
活性剤の $\bar{n} の 2$ 倍上して) 食星は約 $1.7 \%$ になる。こ れに対し曇リ点は $0.8^{\circ} \mathrm{C}$ も変化して打り，結片 $\mathrm{PEG}$ 除去操作により界面活性剛のオキシエチレン鎖長分布と 平均鎖長が変化したものと考えられる。Table-2 に吹 き込み量による $\bar{n}, \mathrm{OH}$-值法による $\bar{n}$ と $\mathrm{PEG}$ を除去 した場合の $\mathrm{OH}$-值法による $\bar{n}$ を比較した。

同様に PEG 除去前後での $\mathrm{OH}$-值法による $\bar{n}$ の值よ り $\mathrm{PEG}$ 含量を計算すると上から順に $2.3,1.2,3.1$, $4.0 \%$ となる。一方曇少の差を見ると 2 番目の場合に $0.9^{\circ} \mathrm{C}$ も変化しており, $\mathrm{PEG}$ 除去操作で $\bar{n}$ が変化した ものと思われる。3 番目の場命の PEG 含量は測定では 
Table-2 Effect of the removal of polyethylene glycols (PEG) on the oxyethylene chain length $(\bar{n})$ evaluated from $\mathrm{OH}$-value and cloud point of nonionic surfactant.

\begin{tabular}{|c|c|c|c|c|}
\hline \multicolumn{3}{|c|}{$\begin{array}{c}\text { Commercial } \\
p, t-\mathrm{C}_{8} \mathrm{H}_{17} \mathrm{C}_{6} \mathrm{H}_{4} \mathrm{O}\left(\mathrm{CH}_{2} \mathrm{CH}_{2} \mathrm{O}\right)_{n}-\mathrm{H}\end{array}$} & \multicolumn{2}{|c|}{ PEG free sample } \\
\hline$\left(\begin{array}{c}\bar{n} \\
\text { evaluated } \\
\text { from the } \\
\text { total ethylene } \\
\text { oxide content }\end{array}\right)$ & $\begin{array}{c}\bar{n} \\
\left(\begin{array}{c}\text { from } \\
\text { OH-value }\end{array}\right)\end{array}$ & $\begin{array}{l}\text { Cloud } \\
\text { point } \\
\left({ }^{\circ} \mathrm{C}\right)\end{array}$ & $\begin{array}{c}\bar{n} \\
\left(\begin{array}{c}\text { from } \\
\text { OH-value }\end{array}\right)\end{array}$ & $\begin{array}{l}\text { Cloud } \\
\text { point } \\
\left({ }^{\circ} \mathrm{C}\right)\end{array}$ \\
\hline 7.0 & 6.49 & 14.7 & 6.67 & 14.3 \\
\hline 8.0 & 7.42 & 41.8 & 7.51 & 40.9 \\
\hline 9.0 & 8.30 & 59.4 & 8.52 & 59.1 \\
\hline 13.0 & 12.03 & 91.4 & 12.29 & 91.5 \\
\hline
\end{tabular}

Cloud point of $2 \mathrm{wt} \%$ aqueous solution

$2.7 \%$ であり上の計算值と一致しており，曇り点の差も 妥当なものであるためこのサンプルは PEG 除去操作で 勿がわずかしか変化していないと考えられる。吹き込ん だエチレンオキシドの一部は PEG となって消費される ため, PEG 除去サンプルの $\bar{n} よ り$ 吹き込み量から求 まる $\bar{n}$ は大きな值となる。また PEG の平均鎖長が界

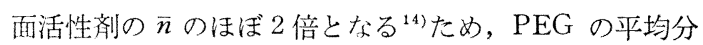
子量㳉界面活性剂の 2 倍より小さく, $\mathrm{OH}$-值法による PEG 除去前の $\bar{n}$ は除去後の $\bar{n}$ より小さくなるはずで あり，実験結果とも合う。

仮に PEG が $1 \%$ 含まれるとすると $\mathrm{OH}$ 值法による $\bar{n}$ の值は $0.07 \sim 0.10(\bar{n}=5 \sim 15)$ だけの誤差を生じる 計算になる (Table-2 中 3 番目の場合の約 3\% 含量で は $0.21 \sim 0.30$ となる計算で，実測值は 0.22 の差を示 しており妥当と見られる)。一方壆り点は著者らの場合 約 $0.1^{\circ} \mathrm{C}$, Schönfeldt の結果 ${ }^{3)}$ では $0.3^{\circ} \mathrm{C}$ 変化する。後 出の Fig.-4 の検量線よりこの温度差ではほぼ $0 \sim 0.04$ だけ $\bar{n}$ が異なることになる。PEG 共存の影響は $\mathrm{OH}$ 值法の方が曇り点法より大きく受けることがわかる。

きょう雑物として触媒を中和させてできた無機塩があ り, 脱塩操作でも一部は界面活性剂中に溶解し除去でき ない。そのため実際に近い条件としてたとえばオクチル フェノールに対し $2 \mathrm{~mol} \%$ カセイソーダを触媒として, 分子量 600 の界面活性剂を作った場合を考えてみる。 このカセイソーダを塩酸で中和させると約 $0.2 \mathrm{wt} \%$ の 食塩が共存することになる。これは $\bar{n} て ゙$ 約 0.03 の誤 差を，墨り点では $0.02^{\circ} \mathrm{C}$ だけ低下させることが予想さ れる ${ }^{18)}$ 結局 $\bar{n}$ 決定に与える影響訬ない。きょう雑物 としての水は今回のポリオキシエチレン, $p$, 第三オク チルフェニルエーテルで $0.1 \mathrm{wt} \%$ 以下であったが, 吸 湿性があり長時間経過したサンプルでは曇リ点法を除い た $\bar{n}$ 決定法に影響が出ることが考えられる。

以上より曇り点法による $\bar{n}$ 決定は PEG などの影響 がほかの方法に比べ少なく, それらの除去操作なしに直 接サンプルを測定しても誤差は少ないと考えられる。

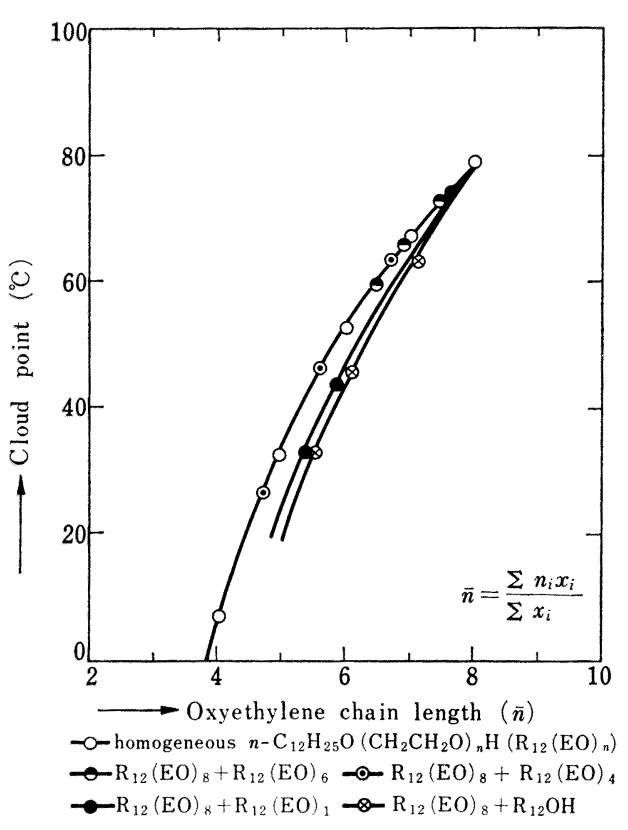

Fig. -1 Effect of mixing of homogeneous $n-\mathrm{C}_{12} \mathrm{H}_{25} \mathrm{O}\left(\mathrm{CH}_{2} \mathrm{CH}_{2} \mathrm{O}\right)_{n} \mathrm{H}$ on the cloud point of $1 \mathrm{wt} \%$ aqueous solution.

\section{$3 \cdot 2$ 纍リ点に及ぼす親水基鎖長分布の影響}

Fig.-1 に単一鎖長オクタオキシエチレン・ドデシル エーテルにやはり同じ種類で鎖長が $0,1,4,6$ の各試 料を加えた場合の数平均分子量と薷少点との関係を示し た。

鎖長が 4 以上の試料の混合では $\bar{n}$ と曇り点の関係が 単一鎖長によるものと同一曲線上にのることがわかる。 これに対して未反応アルコールや極端に短い鎖長のもの を加えた場合には㟟り点が低目にずれてくる。この結果 末反応アルコールや $n$ の極端に短いものを含まない分 布をもつ界面活性郕なら単一鎖長による $n$-量少点の関 係から容易に $\bar{n}$ を推定できることになる。(このことは Fig.-3 の純品と分子蒸留品との量少点がほぼ一致する ことからもわかる)この点で比較的鋭いポアソン分布で $\bar{n}$ が長いものは是り点測定により $\bar{n}$ 推定がかなり精度 良くできることが予想される。Fig.-2 に示すようなポ アソン分布かまたはポアソン分布に近い分布になるよう に混合した試料を調整した。

Fig.-3 亿単一鎖長 ポリオキシェチレン・ドデシルエ ーテルと上記のような分布をもつ各種の混合物の曇リ点 と数平均親水基鎖長との関係を示した。

実際には Fig.-2 とまったく同じ分布の純品混合物は $n=9$ 以上の純品がなく造れなかった。しかしたとえば $n=9$ を含む分布の界面活性剂は, $n=9$ を含まないかわ りに $n=9$ の量だけ $n=7$ を減少させ, かつ $n=8$ を $n$ $=9$ の量の 2 倍量だけ増加させた分布を有する界面活性 


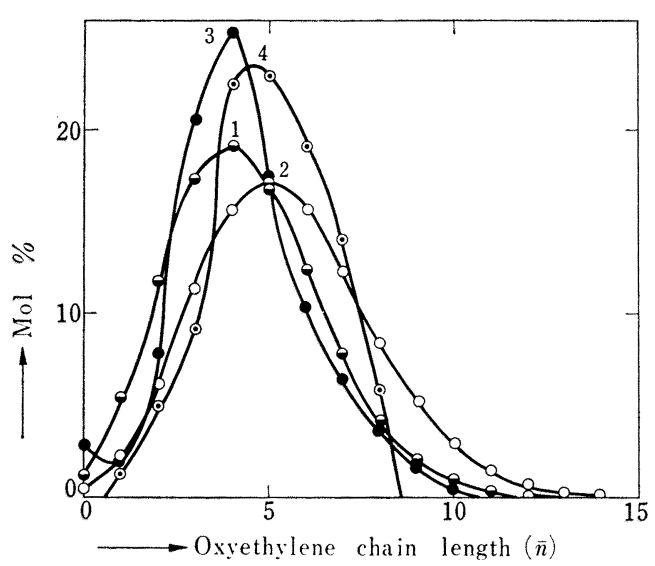

1. a Poisson distribution $(\bar{n}=4.4)$

2. a Poisson distribution ( $\bar{n}=5.5)$

3 . the same distribution as that of a molecularly distilled sample $(\bar{n}=4.3)$

4. a little sharper distribution $(\bar{n}=5.0)$ than that of a molecularly distilled sample

The cloud point of the mixture composed of homogeneous samples $(n \geqq 4)$ depends only on the average oxyethylene chain length. So, the cloud points of the mixtures with these distributions were obtained from the equivalent distributions with the same $\bar{n}_{s}$ using the homogeneous $n$ $\mathrm{C}_{12} \mathrm{H}_{25} \mathrm{O}\left(\mathrm{CH}_{2} \mathrm{CH}_{2} \mathrm{O}\right)_{n} \mathrm{H}(n=0 \sim 8)$.

Fig.-2 Tested distributions of oxyethylene chain length of $n-\mathrm{C}_{12} \mathrm{H}_{25} \mathrm{O}\left(\mathrm{CH}_{2} \mathrm{CH}_{2} \mathrm{O}\right)_{n} \mathrm{H}$ for measuring cloud points.

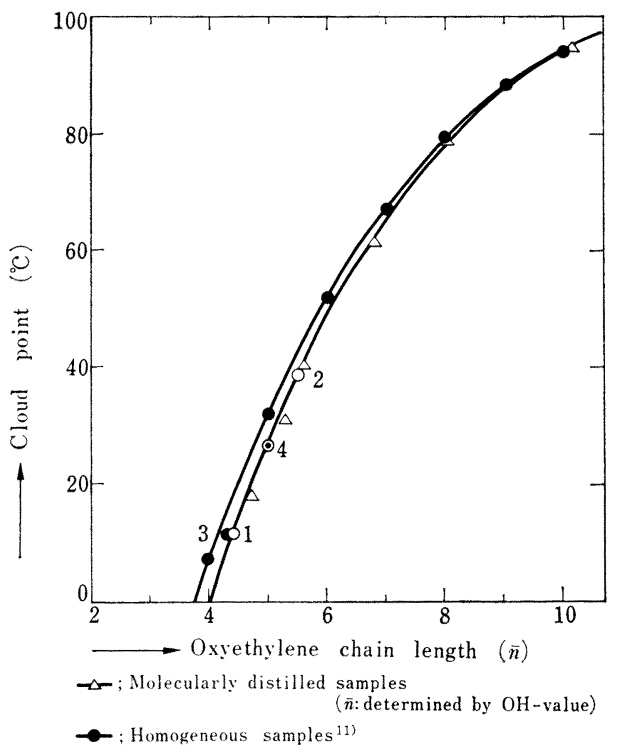

1,2,3 and 4 : Mixtures of homogeneous samples with the distribution illustrated in Fig.-2.

Fig.-3 Effect of the distribution of oxyethylene chain lengths on the cloud point.
剤と同じ曇リ点を示すことが容易に Fig.-1 の結果より 推定できる。この推定に基づき Fig.-2 の各分布中 $n=3$ 以下の混合割合はそのままにして $n=4$ 以上の分布を， それと曇リ点が同じになるように $n=4$ から $n=8$ まで の純品を任意に混合して Fig.-2 に示されるような分布 と同等の界面活性剤を調製した。この界洎活性刻混合物 を用い Fig.-2 の分布の是り点を推定した。

Fig.-3 の図中 1, 2 はポアソン分布を示し，3 は商業 品を分子蒸留したサンプルにつき昇温ガスクロマトグラ フィーにより求めた分布とほぼ同じ分布を示したもの, 4 はやはり商業品を分子蒸留したサンプルとほぼ同じ分 布だが, $n=9$ 以上をカットしてさらに $n=4 \sim 7$ のもの の量を任意に増加させ, 分子蒸留品の分布とはやや異な ったものである。Fig.-3 に分子蒸留品の $\bar{n}(\mathrm{OH}-$ 值法) と雲り点との関係も併記し, 純粋な単一鎖長による曲線 と比較した。図よりポアソン分布や分子蒸留品程度の分 布でかつ $\bar{n}=8$ 以上ではほぼ同じ曲線上にのり， $\bar{n}$ が小 さいほどやや低目に量少点が現われることがわかる。つ まりポアソン分布程度ならその分布からの多少のずれが あっても充分に曇り点 $\bar{n}$ 曲線（ポアソン分布に対す る）から $\bar{n}$ を推定できる。この点からポリオキシェチ レン・アルキルフェニルエーテル類の $\bar{n}$ 決定のために 墨リ点が有效であると考えられる。しかしポリオキシエ チレン・アルキルエーテル類では分布がはるかに広くな り，低重合度のものを含むためロットの違いによるずれ

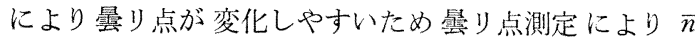
を決定することは誤差が大きく, 分子蒸留品について適 用できるにすぎない。

\section{$3 \cdot 3$ 検量線の作成}

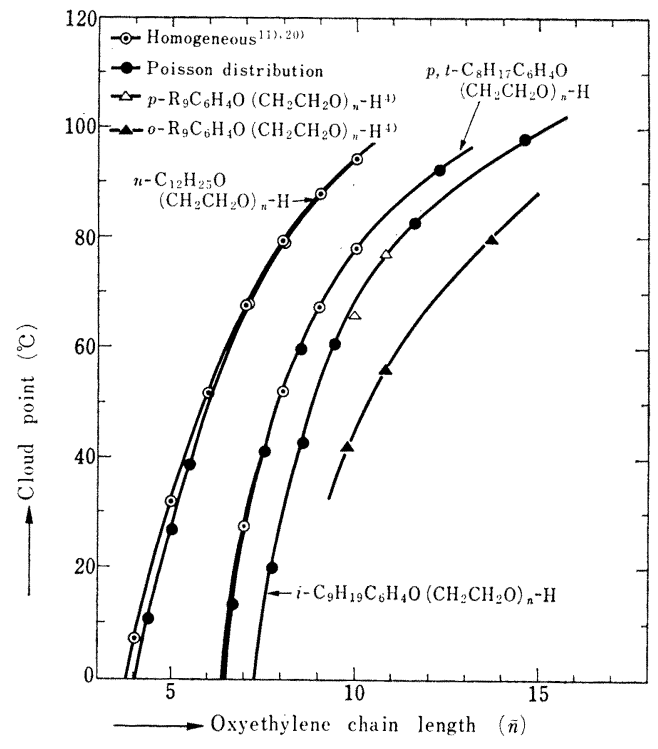

Fig.-4 Calibration curves (cloud point $-\bar{n}$ ) 
これらの実験結果に基づいてポリオキシエチレン・オ クチルフェニルエーテル, ポリオキシエチレン・ノニル フェニルエーテルの昙リ点 $-\bar{n}$ 曲線を求め Fig. -4 に示 した。これらのサンプルはすべて共存する PEG, 無機 塩を除き $\mathrm{OH}$-値法により $\bar{n}$ を決定した。

四よりポリオキシェチレン・p-第三オクチルフェニ ルエーテルの壆リ点 $\bar{n}$ 曲線は Mansfield ら ${ }^{20)}$ にるる単 一鎖長物質による量り点 $\bar{n}$ 曲線に近く，わずかに低温 側にずれていることがわかる。

一方ポリオキシェチレン・ノニルフェニルェーテルの 旺り点-n曲線は Schönfeldt ${ }^{4}$ によるポリオキシェチレ ン・p-ノニルフェニルエーテルの曇リ点と非常に良く 一致している (Schönfeldt の試料は PEG の除去もな されている)。この事実から今回使用した試料中のポリ オキシエチレン・p-ノニルフェニルエーテルの割合が かなり高いことと, 原料中のノニルフェノールの組成が Schönfeldt ${ }^{4)}$ の用いた原料の組成とかなり類似してい ることになり，今回得られた検量線が比較的有用である と考えられる。Schönfeldtによるポリオキシエチレン・ oーノニルフェニルェーテルについても図中に示したがか なり低温側に移行している。そのため原料中にこの 位のノニルフェノールの多い場合にはその割合に志じて 量少点-n曲線を求める必要があるが，いったん検量線 を求めておけ拈じ原料を求めるかぎりほかの方法に比 較しても簡易で精度良い $\bar{n}$ 決定ができる。

\section{$3 \cdot 6$ 曇リ点法の利点}

以上の結果, $\bar{n}$ が極端に短く曇り点が $0^{\circ} \mathrm{C}$ 以下の場

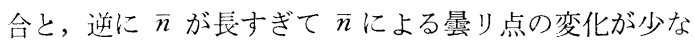
い場合を除いて，ポアソン分布程度の非イオン界面活性 剂なら原料に忘じた量り点と $\bar{n}$ の検量線より $\bar{n}$ を容易 に決定できることがわかった。悬り点そのものは界面活 面剤の水中での溶解状態の変化を示す温度である。さら に水溶液一の油の川浴化量の最大となる温度（油飽和墨 リ点), 油溶液への水の汀溶化量の最大となる温度 (水 飽和晋リ点), 乳化系における転相温度 (親水性と親油 性でちょうどバランスする温度＝HLB-Temperature） と密接に関連している ${ }^{21)}$ 。そのため $\bar{n}$ 決定がなされる だけでなくその界面活性剂の重要な溶解作用や分散作用 を知ることができ，墨り点測定による $\bar{n}$ 決定法は有効
である。

研究に使わ机た各試料を提供していただき, それらの分析值 をお教えいただきました花王石畧株式会社, 荒少明彦博士と木 下郁也氏，両氏に深く感謝いたします。（文責斉藤）

(昭和 48 年 5 月 7 日受理)

\section{文献}

1) N. Schönfe!dt, "Surface Active Ethylene Oxide Adducts”, Chapter 6 (1969), Pergamon Press, Oxford

2) H.G. Nadeau S. Siggia, in "Nonionic Surfactants", M.J. Schick, ed., Crapter 25, and 26 (1967), Marcel Dekker, Inc., New York

3) Ref. 1) p. 152

4) Ref. 1) p. 320

5) Ref. 1) p. 102

6) G. Tischbirek, Proc. Intern. Congr. Surface Activity, 3rd Cologne, Germany, 1, 126 (1960)

7) R.L. Mayhew, R.C. Hyatt, J. Amer. Oil. Chemists' Soc., 29, 357 (1952)

8) J. Kelley, H.L. Greenwald, J. Phys. Chem., 62, 1096 (1958)

9) K. Konishi, S. Yamaguchi, Anal. Chem, 30, 1755 (1966)

10) K. Shinoda, H. Arai, J. Phys. Chem., 68, 3485 (1964)

11) G. Tischbirek, in "Nonionic Surfactants", M.J. Schick ed., p. 430 (1967), Marcell Dekker, Inc., New York

12) T. Nakagawawa, K. Shinoda, in "Colloidal Surfactants", Chapter 2, p. 167 (1963), Academic press, New York

13）日本油化学協会編 “油脂化学便覧” p. 353 (1958), 丸善, 東京

14）長瀬, 坂口, 工化, 64, 635 (1961)

15) R.A. Greff, Jr., R.W. Flanagan, J. Amer. Oil Chemists' Soc., 40, 118 (1963)

16) M.M. Grutchfield, R.R. Irani, J.T. Yoder, J. Amer. Oil Chemists' Soc., 41, 129 (1964)

17) Ref, 2), p. 863

18) K. Shinoda, H. Takeda, J. Colloid and Interface Sci., 32, 642 (1970)

19) C.R. Enyeart, in “Nonionic Surfactants”, M.J. Schick, ed., Chapter 3, p. 50 (1967), Marcel Dekker Inc., New York

20) R.C. Mansfield, J.E. Locke, J. Amer. Oil Chemists'Soc., 41, 267 (1964)

21) K. Shinoda, Vth International Congress on Surface Active Substances, Barcelona (1968); 日化, 89, 435 (1968) 